\title{
Coal Technology Program Progress Report for August 1976
}




\section{DISCLAIMER}

This report was prepared as an account of work sponsored by an agency of the United States Government. Neither the United States Government nor any agency Thereof, nor any of their employees, makes any warranty, express or implied, or assumes any legal liability or responsibility for the accuracy, completeness, or usefulness of any information, apparatus, product, or process disclosed, or represents that its use would not infringe privately owned rights. Reference herein to any specific commercial product, process, or service by trade name, trademark, manufacturer, or otherwise does not necessarily constitute or imply its endorsement, recommendation, or favoring by the United States Government or any agency thereof. The views and opinions of authors expressed herein do not necessarily state or reflect those of the United States Government or any agency thereof. 


\section{DISCLAIMER}

Portions of this document may be illegible in electronic image products. Images are produced from the best available original document. 
Printed in the United States of America: Available from iNational Techunical Inlum maliun Service

U.S. Department of Commerce

5285 Port Royal Ruad, Springfield, Virginia 22161

Price: Printed Copy $\$ 4.00 ;$ Microfiche $\$ 2.25$

This report was prepared as an account of work sponsored by the United States Government. Neither the United States nor the Energy Research and Development Administration/United States Nuclear Regulatory Commission, nor any of their employees, nor any of their contractors, subcontractors, or their employees, makes any warranty, express or implied, or assumes any legal liability or responsibility for the accuracy, completeness nr usefulness nf any information. apparatus, product or process disclosed, or represents that its use would not infringe privately owned rights. 
Contract No. W-7405-eng-26

COAL TECHINOLOGY PROGRAM

PROGRESS REPORT FOR AUGUST 1976

This report was prepared as an account of work
sponsored by the United States Government. Neither
the United States not the United Stgtes Energy
Research and Development Administration, nor any of
their employees, not any of their contractors,
subcontractors, or their employees, makes any
warranty, expsess or implied, or assumes any legal
liability or responsibility for the sccuracy, completeness
or usefunes of any information, apparatus, product or
process disclosed, or represents ihat its use would not
infringe privately owned rights.

NOTICE This document contains information of a preliminary nature and was prepared primarily for internal use at the Dak Ridge National Laboratory. It is subject to revision or correction and therefore does not represent a final report.

\author{
OAK RIDGE NATIONAL LABORATORY \\ Oak Ridge, Tennessee 37830 \\ operated by \\ UNION CARBIDE CORPORATION \\ for the \\ ENERGY RESEARCH AND DEVELOPMENT ADMINISTRATION
}


PREVIOUS REPORTS IN THIS SERIES

ORNL/TM-5044, Progress Report for August 1974

ORNL/TM-5045, Progress Report for September 1974

ORNL/TM-5046, Progress Report for October 1974

ORNL/TM-4787, Progress Report for November 1974

ORNL/TM-4796, Progress Report for December 1974

ORNL/TM-4850, Progress Report for January 1975

ORNL/TM-4873, Progress Report for February 1975

ORNL/TM-4892, Progress Report for March 1975

ORNL/TM-4946, Progress Report for April 1975

ORNL/TM-4966, Progress Report for May 1975

ORNL/TM-5010, Progress Report for June 1975

ORNL/TM-5037, Progress Report for July 1975

ORNL/TM-5092, Progress Report for August 1975

ORNL/TM-5124, Progress Report for September 1975

ORNL/TM-5186, Progress Report for October 1975

ORNL/TM-5214, Progress Report for November 1975

ORN/TM-5246, Progress Report for December 1975

ORNL/TM-5301, Progress Report for January 1976

ORNL/TM-5321, Progress Report for February 1976

ORNL/TM-5430, Progress Report for March 1976

ORNL/TM-5479, Progress Report for April 1976

ORNL/TM-5532, Progress Report for May 1976

ORNL/TM-5595, Progress Report for June 1976

ORNL/TM-5611, Progress Report for July 1976 
CONTENTS

Abstract .. . . . . . . . . . . . . . . . . . 1

1. Summary ......................... . . I

2. Hydrocarbonization Research . . . . . . . . . . . . . 3

2.1 Bench-Scale Hydrocarbonization System . . . . . . . . . 3

2.2 Residue Carbonization . . . . . . . . . . . . . . . 4

3. Supporting Research and Development in Separations Technology . . 5

3.1 Characterization Tests . . . . . . . . . . . . 5

3.2 Laboratory-Scale Tests . . . . . . . . . . . . 6

3.3 Bench-Scale Tests . . . . . . . . . . . . . . 6

3.4 Dissemination of Information . . . . . . . . . . 6

4. Experimental Engineering Support of an In Situ

4.1 Large-Block Pyrolysis Studies . . . . . . . . . . . 8

4.2 LRDA's UCG Program . . . . . . . . . . . . . . 8

5. Analytical Chemistry . . . . . . . . . . . . . . . 9

5.1 Analytical Services . . . . . . . . . . . . . 9

6. Engineering Studies and Technical Support . . . . . . . . . 10

6.1 Synthoil Process . . . . . . . . . . . . . . 10

6.2 Hydrocarbonization Process . . . . . . . . . . . . . Il

6.3 Prncess Modeling Support . . . . . . . . . . . . . . 12

6.4 Process Research Digest... . . . . . . . . . . 12

7. Coal-Fueled MIUS . . . . . . . . . . . . . . . . . 13

7.1 Furnace Procurement . . . . . . . . . . . . . . 13

7.2 Turbine-Generator Unit . . . . . . . . . . . . 13

7.3 Site Preparation . . . . . . . . . . . . . . . 13

7.4 Cold Hlow Tests uf a Fluidized Ded . . . . . . . . . . 14

7.5 Coal Metering and Feed System............... 14

7.6 Ash Handling System . . . . . . . . . . . . . . . 14

7.7 Supplemental studies . . . . . . . . . . . . . 14 
Page

8. Materials . . . . . . . . . . . . . . . . . 15

8.1 Pressure Vessel and Piping Technology Assessment . . . . . . I6

8.2 Inspection Techniques for Wear- and Process-

Resistant Coatings .................. 16

8.3 Iron and Nickel Carbonyl Formation and Prevention . . . . . I8

8.4 Failure Analysis of Materials and Components . . . . . . . . 18

8.5 Prestressed Concrete Pressure Vessel Studies . . . . . . 18

8.6 Other Related Work . . . . . . . . . . . . . . 20

9. Process and Program Analysis . . . . . . . . . . . . . . . 21

9. I Low Btu Coal Gas . . . . . . . . . . . . . . . . . . . . .

$9.2 \mathrm{High} \mathrm{Btu} \mathrm{Gas} \mathrm{.} \mathrm{.} \mathrm{.} \mathrm{.} \mathrm{.} \mathrm{.} \mathrm{.} \mathrm{.} \mathrm{.} \mathrm{.} \mathrm{.} \mathrm{.} \mathrm{.} \mathrm{.} \mathrm{.} \mathrm{.} \mathrm{.} \mathrm{.} \mathrm{.} 22$

9.3 Direct Combustion ................. . . 22

9.4 Liquefaction . . . . . . . . . . . . . . . 22

9.5 Advanced Power/Combined Cycle . . . . . . . . . . . 22

9.6 In-Situ Coal Gasification . . . . . . . . . . . . . 22

9.7 Subsystems . . . . . . . . . . . . . . . . 22

10. Alternate Contactors for Noncatalytic Hydroliquefaction

of Coal . . . . . . . . . . . . . . . . . . . . 23

10.1 References for Section 10 . . . . . . . . . . . 23 
COAL TECHNOLOGY PROGRAM PROGRESS REPORT FOR AUGUST 1976

\section{ABSTRACT}

This report - the twenty-fifth of a series - is a compendium of monthly progress reports for the ORNL research and development projects that are in support of the increased utilization of coal as a source of clean energy. The projects reported this month are those for hydrocarbonization research, solids-liquid separations, in situ gasification; analytical chemistry, materials engineering, engineering studies, process and program analysis, coal-fueled MIUS, and novel contactor development.

\section{SUMMARY}

J. P. Nichols

Highlights of our progress in August are summarized below:

- In our hydrocarbonization research project we successfully completed our first experiment utilizing the hydrocarbonization reactor in a recirculating fluidized bed mode.

- A residue carbonization experiment was completed in which there was no significant agglomeration in the fluidized bed reactor but which was terminated prematurely because of a plug in the off-gas line.

- In our solids-liquid separations work we continued characterization and settling tests of oils derived from the SRC process.

- In our high-temperature coal block pyrolysis studies we completed experiments to fill out a matrix of pyrolysis data as a function of heating: rates at atmospheric pressure.

- In our engineering studies and technical support work we completed engineering evaluations of commercial-sized Synthoil and "Hydrocarbonization plants. We also initiated a project to provide Process Research Digests for the ERDA Division of Fossil Energy Research.

- In our Coal-Fueled MIUS project we received bids for fabrication of the fluidized bed combustor and continued tests of system components.

- In our Materials Engineering work we continued experiments to develop inspection techniques for thin coatings and continued design studies of prestressed concrete pressure vessels. We also completed the assembly of our apparatus for measuring the formation rates of metal carbonyls. 
- We initiated a new project to provide process and program analysis research studies for the ERDA Fossil Energy Office of Program Planning and Analysis.

- We also initiated a new project to develop better contactors for the noncatalytic hydroliquefaction of coal. 


\section{HYDROCARBONIZATION RESEARCH}

H. D. Cochran, Jr.

\subsection{Bench-Scale Hydrocarbonization System}

H. D. Cochran, Jr., G. L. Yoder, P. R. Westmoreland, C. H. Brown, and J. C. Rose

\subsubsection{Work Accomplished}

Design and Review. There was no effort to be reported in this area during August.

Fabrication and Installation. Modification of the bench-scale system for recirculating fluidized bed operation was completed early in August. An updated flowsheet is shown in Fig. 2.1. Changes from earlier flowsheets include the draft tube, coal feed location, and gas feed lines.

Coal for hydrocarbonization (and other solids sizing jobs at the Laboratory) can now be ground and sieved in a solids handling facility (Fig. 2.2); new and existing equipment from several other projects has been located in Bldg. 4501, Rm. 112. Drum quantities of solids can be dried, mixed, ground, and sized in a series of dust-free, inert gas blanketed operations. Equipment is also available to dry, mix, grind, and size small quantities of solids. Modification of the existing facility and installation of equipment is nearly completed.

Operation. The recirculating fluidized bed reactor was successfully tested during August in Experiment HC-7, hydrocarbonization of Wyodak subbituminous coal fed at $14.8 \mathrm{lb} / \mathrm{hr}$ for $6.9 \mathrm{hr}$, operating at $820^{\circ} \mathrm{F}$ and 300 psig. Minor difficulties with the electrical heaters and controllers limited operation to below design temperature.

Steady-state gas composition and preliminary material balances were determined for Experiment $\mathrm{HC}-7$. Consistent deficiencies in overall mass, carbon, and ash balances are being investigated.

Aqueous samples from Experiments $\mathrm{HC}-5$ and $\mathrm{HC}-6$ were analyzed for carbon. content, and carbon balances were corrected. Data from all experiments are being critically reviewed so that final material balances may be issued. 


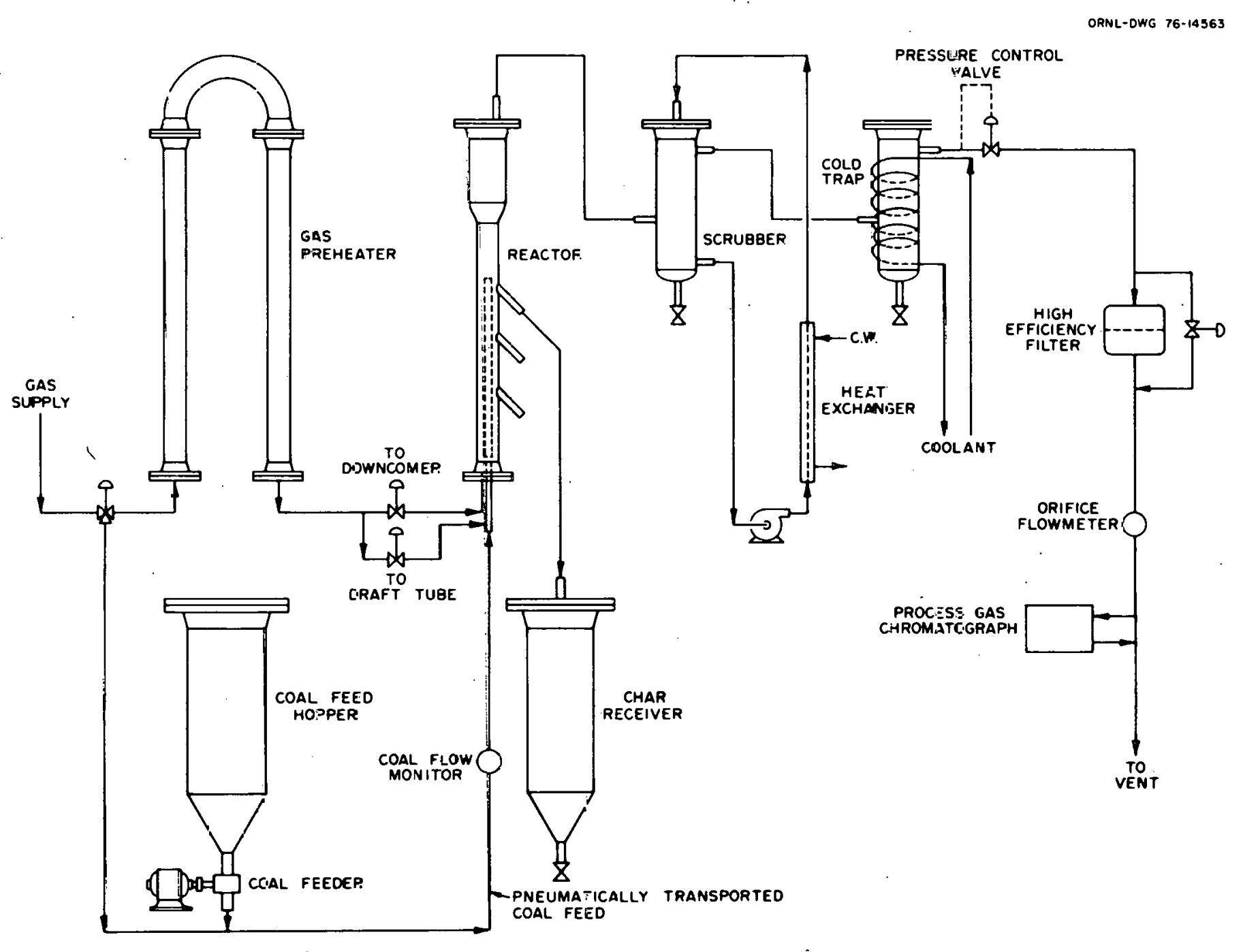

Fig. 2.1. Bench-scale hydrocarbonization flcwsheet. 


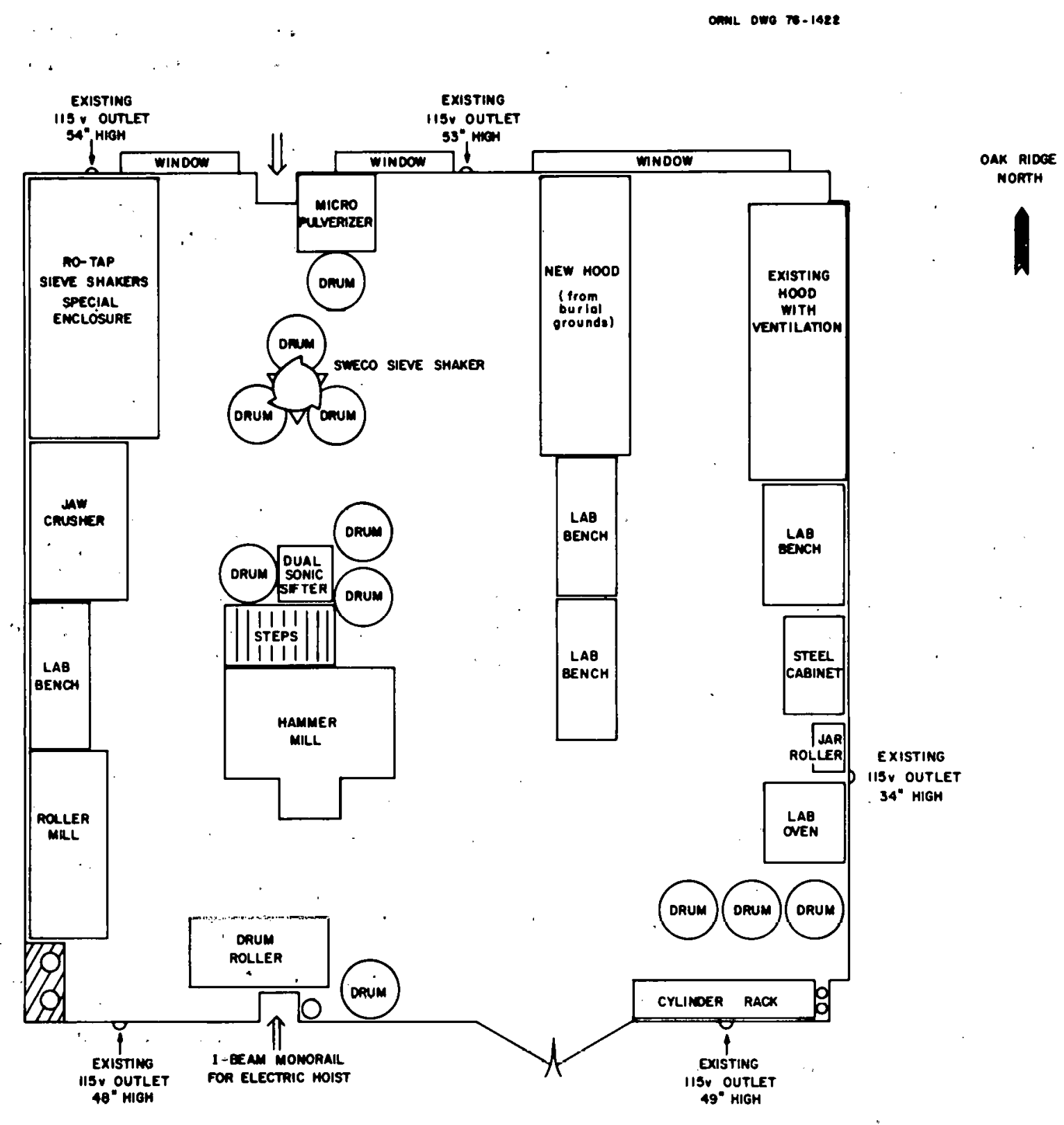

LAB I12, BUILDING 450 I

Fig, 2.2. Solids handling faclitty. 


\subsubsection{Work Forecast}

Design and Review. No effort is planned in this area.

Fabrication and Installation. The solids handling facility will be sufficiently completed during September that coal preparation may begin. Repairs and minor modifications to the heating system on the hydrocarbonizer will be made.

Operation. Coal for the bench-scale system will be prepared during September. When sufficient coal is readied, a series of experiments invertigating recirculating fluidized bed hydrocarbonizalion will begin.

\section{Residue Carbonization}

H. I. Cochran, Jr., J. B. Gizbson, and R. L. Andrews

\subsubsection{Work Accomplished}

One residue carbonization run, $\mathrm{RC}-13$, was performed in August. The temperature of the mun was $1230^{\circ} \mathrm{F}$, and the feed rate was $3 \mathrm{lb} / \mathrm{hr}$ at a 4:1 ratio of Wyodak char to residue. As with the previous two muns, run RC-13 lasted about $\mathrm{I} \mathrm{hr}$ and was terminated when a plug developed in the 1/2-in. pipe leading from the reactor to the cyclone. Analysis of gas samples taken during the run showed small quantities of $\mathrm{H}_{2}, \mathrm{CH}_{4}, \mathrm{CO}$, and $\mathrm{CO}_{2}$.

Several runs have now been made in which there was little or no agglomeration in the reactor, but extensive solids carryover and plugging downstream of the reactor have terminated these runs. Modifications to the residue carbonizer are being designed which should minimize these problems. These modifications will include the addition of a 3-ft section with an 8-in. -diam expanded head to the top of the reactor and the addition of a high efficiency internal cyclone which will eliminate the 1/2-in. pipe connecting the reartior and the previous cyclone. Other modifications will include replacing the flat bottom of the scrubber with a conical bottom to make recovery of liquids easier and replacing the ball valve feeder with a specially designed plug valve to increase feeding rates.

\subsubsection{Work Forecast}

Modifications to the residue carbonizer can be completed in September and carbonization experiments with residue will resume near the end of the month. 


\section{SUPPORTING RESEARCH AND DEVELOPMENT IN SEPARATIONS TECHNOLOGY}

B. R. Rodgers

\subsection{Characterization Tests}

B. R. Rodgers and D. A. McWhirter

\section{Ageing}

After ageing for 10 months under various storage conditions, analyses of Solvent Refined Coal (SRC)--Filtered Oil (FO) indicate continued stability of physical and chemical properties. The Unfiltered Oil (UFO), after ageing for 6 months, continued to show increases in oxygen content and a loss of carbon and hydrogen. However, the carbon/hydrogen ratio remained stable at $\sim 12.3$. The one-year FO analyses scheduled next month will terminate the study of ageing characteristics of that material, but the UFO ageing analyses will continue for two additional months. As pointed out previously, mislabeled UFO samples from the SRC plant at Wilsonville, Alabama, caused a delay in placing the latter samples in storage.

\section{Paraffinic analyses of settler overflows}

Paraffinic analyses of the upper phase of settled UFO and UFO $+20 \%$ n-decane have provided some interesting information. Analysis of the neat UFO (UFO only) gave 2.5 wt \% paraffins. Analysis of the UFO $+20 \%$ n-decane solution gave $1.3 \mathrm{wt} \%$ paraffins on an $\mathrm{n}$-decane-free basis. The net loss to a process (assuming $70 \%$ overflow and total recovery of $n$-decane in overflow) would be 10.3 wt $\%$ of the n-decane originally added as precipitant. Process solvent losses at this level would not be tolerable using a pure compound. This result stresses the importance of studying the process recovery characteristics of paraffinic solvents used for de-ashing. For instance, a process similar to SRC using paraffinic process-derived precipitant would have to yield an amount of precipitant equal to $2.6 \mathrm{wt} \%$ of the reactor effluent in order to make a de-ashing solvent balance.

Using 20\% toluene as agglomerator, the paraffin content of the overflow increased to 5.1 wt \%. The aromatic content of this overflow, its recovery, and its effect on process recycle solvent needs to be studied further.

\section{Simulated distillations of aged samples}

The SRC-FO samples which had been aged for 10 months generally showed higher boiling points for a given cut point (\% distilled overhead). For example, the sample stored at $140^{\circ} \mathrm{F}$ required a temperature of $257^{\circ} \mathrm{C}$ for $50 \%$ distillation, compared to $210^{\circ} \mathrm{F}$ for a sample stored under the same conditions fur 6 months. The UFO $50 \%$ cut point remained fairly steady at $\sim 270^{\circ} \mathrm{C}$. 
Viscosity-temperature dependence of SRC-UFO from

the Ft. Lewis SRC plant

The dependence of viscosity of SRC-UFO from the PAMCO pilot plant on temperature was measured using a Cannon-Fenske viscometer. Genera11y, the viscosity was very similar to that of a sample from the Wilsonville, Alabama plant (reported in ORNL/TM-4968). For instance, at $150^{\circ} \mathrm{C}$ the PAMCO SRC-UFO viscosity was $53.5 \mathrm{cP}$ compared to $56.3 \mathrm{cP}$ for the Wilsonville material. For temperatures greater than $150^{\circ} \mathrm{C}$, the PAMCO material had higher viscosities, and at process conditions $\left(500^{\circ} \mathrm{F}\right)$ the viscosity was twice that of the Wilsonville material (6 cP compared to $3 \mathrm{cP}$ ).

\section{1.) Tahnratergy=Seale Teste}

\section{B. R. Rodgers and D. A. McWhirter}

\section{Solids content of agglomerated SRC-UFO}

Last month the dry solids content of SRC-UJFO, after the addition of $20 \%$ n-decane and $20 \%$ toluene at room temperature, was reported as 17.8 and $\overline{8} .3$ wt \%, respectively. This should be compared to $6.8 \mathrm{wt} \%$ for neat UFO. Additional analyses using the same $1.2 \mu$ Millipore filtration technique gave values of 8.8 and $6.8 \mathrm{wt} \%$ for SRC-process-derived light oil and wash solvent, respectively. Differences were more pronounced at high solvent-to-oil ratios. For $\mathrm{s} / 0=12 / 1$, n-decane precipitate was 35 wt $\%$ of original UFO, light oil and toluene were $18 \%$, and wash solvent remained at 6.8 wt \%.

\subsection{Bench-3cale Tests}

\section{B. R. Rodgers and D. A. McWhirter}

Two additional settling runs at $530^{\circ} \mathrm{F}$ using a $200-300^{\circ} \mathrm{F}$ cut of light oil and a $400-500^{\circ} \mathrm{F}$ cut of wash solvent as $20 \%$ diluent in SRC-UFO gave results similar to those reported in the annual interim report (ORNL-5208). For instance, the time required to obtain $70 \%$ by volume clarified overflow was 1.4 and 2.2 hours, respectively, for the two cuts above, compared to 1.4 and 2.0 for light oil and wash solvent.

\subsection{Dissemination of Information}

\section{B, R. Rodgers}

A presentation and discussion of mutual results was made at Gulf Research and Development Company on August 16 and at Conoco Research and Development on August 17. The meeting at Conoco was particularly useful since representatives of Fluor, Inc., PAMCO, and ERDA were present. 
A project review meeting and discussion of fiscal year 1977 plans was made at ERDA Headquarters and included members from DCCU. The interaction was very fruitful and it is anticipated that this type of meeting will become more frequent. 
4. EXPERIMENTAL ENGINEERING SUPPORT OF AN IN SITU GASIFICATION PROCESS

R. C. Forrester III

\subsection{Large-Block Pyrolysis Studies}

R. C. Forrester III and G. D. Owen

Investigation of two-dimensional pyrolysis effects has continued this month with tests conducted at heating rates of 0.3 and $3.0^{\circ} \mathrm{K} / \mathrm{min}$ to a temperature maximum of $1273^{\circ} \mathrm{K}$. These tests complete the ma.trix. of temperatures and heating rates to be studied at atmospheric pressure under inert atmospheres. A few repeat tests are planned in the coming months, as well as some "special-conditions" experiments designed to elucidate specific pyrolysis mechanisms which are thought to be taking place.

\subsection{ERDA's UCG Program \\ R. C. Forrester III}

The 2nd Annual Underground Coal Gasification Symposium, sponsored by the Morgantown Energy Research Center, ERDA, was held at the Lakeview Inn and Country Club, Morgantown, West Virginia, August 10-12. Every participant in UCG development in the United States was represented, as were a number of international organizations. Much current information was presented both formally and informally, and recent results of the ORNL experimental program were summarized in a paper entitled, "TwoDimensional Studies of Coal Pyrolysis: Preliminary Results." The entire proceedings of the meeting will be published and are expected to be available by December. Reprints of the ORNL paper are already available. 


\title{
5. ANALYTICAL CHEMISTRY
}

W. R. Laing

\subsection{Analytical Services}

\author{
L. J. Brady
}

During the month a total of 145 samples were submitted for analysis. A total of 97 samples from the solids-liquid separation program were tested the first week of this period. Since then no samples of this type have been received.

Two samples of coal-derived liquids were submitted for the determination of the simulated boiling range.

Three sets of samples comprising a total of 56 samples were tested for the concentration of $\mathrm{CO}, \mathrm{N}$, and $\mathrm{CH}_{4}$. In addition, six of these samples were tested for $\mathrm{CO}_{2}$ content.

A molecular sieve column is used to separate $\mathrm{CO}, \mathrm{N}$, and $\mathrm{CH}_{4}$. A separate portion of the sample is separated on a silica gel column in order to determine $\mathrm{CO}_{2}$. 
6. ENGINEERING STUDIES AND TECHNICAL SUPPORT

J. R. McWherter and R. Salmon

\subsection{Synthoil Process}

R. Salmon, E. G. St. Clair, M. S. Edwards, W. C. Ulrich, and D. A. Dyslin

The engineering evaluation of the Synthoil process was completed, and the draft report was issued on schedule. Copies of the report were submitted to ERDA/FE, Fossil Demonstration Plants Division. Preparation of a final report will proceed after receipt of comments from ERDA/FE.

The estimated overall capital investment for the $100,000 \mathrm{~B} / \mathrm{SD}$ Synthoil facility is $\$ 1897$ million, consisting of $\$ 1668$ million depreciable and $\$ 229$ million nondepreciable capital. The cost of the coal mine is not included. Coal delivered to the plant is considered as an operating expense, and its cost is treated as a variable in the economic analysis. Interest during construction is not included in the capital investment, but is accounted for in the calculation of the product price. All costs are on a first-quarter 1976 basis.

Using the discounted cash flow procedure, the price of product oil was calculated as a function of coal cost and annual after-tax rate of return on equity capital. This was done for four capital structures ranging from $100 \%$ equity to $95 \%$ debt, using an annual interest rate on Qebt of 9\%. By-product credits were included for sulfur at $\$ 60 /$ Iong ton and anhydrous ammonia at $\$ 160 /$ ton. Results were based on a federal. income tax rate of $48 \%$, a state income tax rate of $3 \%$, and a federal investment tax credit of $7 \%$. Project duration was 25 years, consisting of a 5-year construction period followed by a 20-year operation period. 


\subsection{Hydrocarbonization Process}

J. M. Holmes, D. A. Dyslin, M. S. Edwards,

D. S. Joy, G. R. Peterson, and C. B. Smith

A preliminary design and an economic evaluation of a hydrocarbonization facility. based on U. S. Steel Corporation's Clean Coke process is completed and two peports have been issued. Volume 1 includes the conceptual design and cost estimate of a commercial facility for producing clean char, oil, and pipeline gas fuels having a heating value comparable to $100,000 \mathrm{bbl}$ of fuel oil per day. The conceptual design includes a complete f'acility that will: (1) prepare the coal for hydrocarbonization in a beneficiation system; (2) hydrocarbonize a fraction of the beneficiated coal to solid, liquid, and gaseous fuel products; (3) provide energy to the facility by burning the remainder of the beneficiated coal in a fluidized-bed combustor;

(4) hydrotreat the liquid products using hydrogen produced internally, and

(5) treat the plant effluents to comply with regulations concerning disposal. The total capital investment, including initial working capital, initial raw materials, catalysts and chemicals, and land, is about \$1019 million. A discounted cash flow analysis assuming 100\% equity financing, $12 \%$ return on equity, and coal priced at $\$ 20 /$ ton resulted in a product fuel price of $\$ 3.15 /$ million Btu. An alternative process where the coal liquids were marketed without hydrotreatment or filtration resulted in a product price of $\$ 2.77 /$ million Btu.

Volume II of a two-volume study concerning the preliminary design and economic evaluation of a hydrocarbonization facility includes: (1) a review of the current status of the major processing units, (2) an assessment of operating problems, (3) considerations of possible process alternatives, (4) an evaluation of the overall process feasibility, and (5) recommendations for future process development. Results of the study emphasize the need for testing the evaluated process, which is based on the Clean Coke process, in a continuous pilot plant using a wide variety of highly caking bituminous coals as feed material. A program suggested for the pilot plant would encompass: (1) development of improved methods for the prevention of agglomeration of highly caking coals during hydrocarbonization, (2) optimization of the yields of coal liquids, (3) investigation of a single-stage high-temperature hydrocarbonizer optimized for char production, and (4) optimization of beneficiation ratios employed during coal preparation. 


\section{3 Process Modeling Support}

R. Salmon, D. S. Joy, J. K. Huffstetler

This project is a joint effort involving Purdue University, Lehigh University, and ORNL. The overall objective is to develop computer programs for the design and cost estimation of coal conversion processes and facilities. Purdue is concentrating on the development of steadystate mass and energy balance process design models; Lehigh on unsteadystate models. ORNL's computer facilities will be used for implementing the Purdue and Lehigh programs. ORNL will also help in developing, augmenting, and updating the programs, especially in the areas of equipment design and cost estimation.

A list was provided to ERDA/FE, Purdue and Lehigh Universities of all reports in the ORNL Coal Technology Information Center. Assistance will be provided by ORNL in obtaining information as necessary.

\subsection{Process Research Digest}

F. J. Endelman

Work on this project was initiated and details of the work statement confirmed in August.

Much of the organizational groundwork for publishing a triannual Process Research Digest.(PRD) was accomplished in this reporting period. The Principal Investigator will serve as Editor of the Digest. He will supervise the work of an ORNL research staf' member serving as a full time technical writer, and a production team from ORNL's Technical Publications staff.

The PRD staff is finalizing a publication schedule and is awaiting distribution by DFER of a letter of introduction to appropriate DFER contractors. This should greatly facilitate accumulation of the information to be reported upon in each issue of the Digest. 


\section{COAL-FUELED MIUS}

A. P. Fraas and W. R. Mixon

This project for analysis, design, and demonstration of a concept utilizing a fluidized-bed coal combustion system as a heat source for a gas turbine generator suitable for applications in Modular Integrated Utility Systems (MIUS) is carried out under the ORNL-HUD-MIUS Program within the Energy Division. Work is supported by the U.S. Department of Housing and Urban Development under HUD Interagency Agreement No. IAA-H-40-72 and by the Energy Research and Development Administration, Office of Fossil Energy (formerly Office of Coal Research, Department of the Interior), under ERDA Contract No. E(49-18)-1742. The project consists of four phases: I - Conceptual Preliminary Evaluation; II - Conceptual Design; III - Detailed Design and Construction; and IV - Shakedown, Performance, and Endurance Tests.

\section{I Furnace Procurement}

Bids for fabrication of the furnace and tube bundles were received from two vendors. The bids are being evaluated for possible placement of the order upon receipt of additional funds. The present bids are valid until october 18, and the order will have to be placed by then to be assured of the bid price.

Consideration is being given to seeking bids on the basis of performance specifications with each vendor providing their own design. This has the potential advantage of providing a more economical and more nearly commercial design. Primary disadvantages would be delays in procurement and the need for additional design work.

\subsection{Turbine-Generatonr Init.}

Analysis of the existing electronic control package and design of instrumentation and controls for the turbine continued.

\subsection{Sitc Preparation}

The drawings for relocation of existing equipment were nearly completed. The decision was made to enlarge the control room and drawings for that change were near completion. 


\subsection{Cold Flow Tests of a Fluidized Bed}

Fluidizing tests were completed and heat transfer tests are in progress using smaller sized limestone in the small cold flow model. The results indicate a considerably lower fluidizing velocity and a.higher heat transfer coefficient than had been expected. Performance over a wide range of fluidizing velocity is yet to be determined.

\subsection{Coal Metering and Feed System}

Endurance running of the fllow splitter feed system continued at full design power coal feed rate. The system has been operated for a total of $175 \mathrm{hr}$ and no operating problems have been encountered.

Endurance testing on a prototype coal feed nozzle was continued. The nozzle has been tested for a total of $95 \mathrm{hr}$ with no observed difficulties.

Drawings are in preparation for modifications that will allow continuous operation of the flow splitter feed system with the objective of running a 1000-hr endurance test.

\subsection{Ash Handling System}

Work is proceeding on ash handling system design based on the option of procuring individual components.

\subsection{Supplemental studies}

About half of the corrosion test specimens are ready for shipment to Fluidyne. The balance of the specimens include Alonized sections which will be prepared early next month.

Heat transfer tests in the FluiDyne furnace were completed this. month. The data will be analyzed and the report prepared next month.

The first draft of the report on system performance with alternate cycles has been completed. 


\section{MATERIALS}

\section{W. R. Martin and D. A. Canonico}

The materials engineering and supporting technology reported herein are in support of activities directed by Materials and Power Generation, Division of Fossil Energy Research. Other related work not funded directly by this division of ERDA/FE is included also.

\section{Summary}

Chapters of the Pressure Vessel and Piping Assessment have been reviewed by ERDA/FER, and we are including recommended changes to our manuscript. Revised chapters are being returned to FER for additional review.

We have prepared executive summaries for a forthcoming ERDA Materials Meeting, and they have been transmitted to ERDA/FER.

In our Inspection Techniques for Wear and Process-Resistant Coatings Program, our first coating thickness standards have been coated with a single layer ceramic $\left(\mathrm{ZrO}_{2}\right)$ and returned to the shop for final machining. Free-standing specimens of $\mathrm{ZrO}_{2}$ (for properties determination) have been prepared by spraying on a smooth $\mathrm{Ni}$ substrate, from which the full coating spalis, almost in one piece, upon cooling.

We have initiated procurement of an x-ray fluorescence measurement system similar to one used at $\mathrm{Y}-12$ for preliminary work. Thermal computer code calculations are continuing. We are now preparing to generate thermal profile curves to show the response to an unbond flaw. We are assembling experimental equipment to verify the computational results. We have made preliminary eddy current measurements on free-standing coating layers. Initial stressing of the crack specimen for penetrant testing has been done; stressing at higher levels will be required. A scanning device to control spacing has been built for high voltage probe experiments.

In our Prestressed Concrete Vessel Studies, detailed analysis work is continuing in order to finalize the conceptual designs. Initial vessel drawings are for Synthane. Studies continued on the materials for a two-layer refractory liner system. Difficulties in conducting the thermal analyses for the liner-vessel interface are being overcome. Several methods were examined for mechanically holding the refractory liners in place and to transfer lever loads to the vessel. A double-anchoring system using stainless steel anchors appears to be the best choice. 


\subsection{Pressure Vessel and Piping Technology Assessment}

D. A. Canonico, R. H. Cooper, R. K. Nanstad, G. C. Robinson, and G. M. Slaughter

This Assessment Program will identify those areas where additional material property data needs are required for pressure vessels and piping. The goal is to assure that the pressure vessels and piping in conversion systems can be designed, fabricated, and operated in a safe and reliable manner.

Fossil Energy Research (FER) has reviewed some chapters of the report, and their suggestions are being incorporated in the report. The Materials Selection chapter has been revised and will be transmitted to FER. Executive summaries for the forthcoming ERDA Materials Meeting were prepared and transmlted to ERDA/FER.

\subsection{Inspection Techniques for Wear- and Process-Resistant Coatings \\ R. W. McClung and G. W. Scott}

\subsubsection{Review and Evaluation (G. W. Scott)}

An executive summary of the current status of coating inspection work was prepared for the AGA-EPRI-ERDA Materials Meeting (Washington, D. C., September 30-October 1, 1976) and mailed on August 13. A set of posters (3) is being prepared for exhibition at the Annual ORNL Metals and Ceramics Division Advisory Committee Review and Information Meeting on September 15 and 16. The latter part of this meeting will include invited guests from other institutions and the technical press.

\subsubsection{Specimen and Standard Fabrication (J. D. Hudson and D. P. Edmonds)}

The Welding and Brazing Laboratory is preparing plasma sprayed coatings to be used for development of nondestructive examination (NDE) techniques. We have sprayed several $\mathrm{ZrO}_{2}$ coatings on Incoloy 800 substrates, with no bond coat. The following samples have been prepared:
(a) $0.254-\mathrm{mm}(0.010-\mathrm{in}$.$) thick coatings on 3.175-\mathrm{mm}$ (U.125-in.) thick Inculoy 800 ;
(b) $0.127-\mathrm{mm}(0.005-\mathrm{in}),. 0.254-\mathrm{mm}(0.010-\mathrm{in.})$ and $0.381-\mathrm{mm}(0.015-\mathrm{in}$.) thick coatings on thickness standards (Incoloy 800 substrates); and
(c) 0.254-mm (0.010-in.) thick free-standing coatings for eddy current evaluation.


Uniform thickness standards are obtained by spraying slightly thicker than desired coatings on accurately machined substrates and surface grinding to the desired thickness. Free-standing samples (no substrate) are obtained by spraying directly onto a nickel substrate, from which the coating layer easily spalls away. Presently, we are preparing sprayed coatings using $\mathrm{NiCr}$ and $\mathrm{NiCrAl}$ bond layer materials.

Since surfaces to be plasma sprayed must first be sandblasted, we are investigating the effects of this sandblasting on the substrate. We found that when a minimum amount of sandblasting is performed, the apparent substrate thickness increases by $0.025-\mathrm{mm}(0.001-i n$.) for Incoloy 800 . We are performing a metallographic examination to observe the effects of $s$ andblasting on the microstructure and to determine if a dimensional correction is required. Also, we are investigating the effects of different spraying techniques on the coating density.

\subsubsection{Radiation Testing (B. E. Foster)}

We have initiated procurement of an $x$-ray fluorescence measurement system similar to that which was used earlier at the $Y-12$ plant. Our system will have higher sensitivity and better resolution than the $\mathrm{Y}-12$ system, and will include some additional features which will be useful in development of advanced techniques.

\subsubsection{Thermal Testing (W. A. Simpson, Jr.)}

We are continuing to generate computer data on the propagation of heat in the coating-substrate system for the evaluation of bond quality of resistant coatings. The results to date indicate that thermal testing should be a viable technique for evaluating the bond integrity of the coating. We are attempting to generate curves which will give the thermal contrast (defined as the temperature difference between bonded and unbonded regions under identical heat injection conditions) as a function of time and heat injection rate. This will allow us to optimize the heat input to the sample and to determine the appropriate time "window" in which to measure the surface temperature distribution.

In order to test these computer predictions, we are assembling the equipment necessary to experimentally evaluate the samples. Because of the very rapid development and dissipation of the non-bond thermal profile, as predicted by the computer, a fast response detector will be necessary to capture the transient. We have such a detector in the form of a liquid nitrogen cooled infrared camera that can be operated as a point source radiometer. We are also investigating the possibility of using a very low mass, fast response thermistor, which we have on hand. Suitable heat injection sources are also being investigated with top priority going to a plasma jet torch. 


\subsubsection{Eddy Current Testing (C. V. Dodd)}

We have successfully made free-standing layers of sprayed $\mathrm{ZrO}_{2}$ in the 0.010-0.020-in. range of thickness. Preliminary measurements indicate very low conductivity, just slightly above that of ambient air. By comparison, a high-purity $\mathrm{Al}_{2} \mathrm{O}_{3}$ circuit substrate had a conductivity slightly less than that of air.

\subsubsection{Liquid Penetrant Testing (S. D. Snyder)}

The first artificial-crack specimen coated with $\mathrm{ZrO} 2$ for liquid penetrant experiments was stressed in a tensile machine to a load of $2850 \mathrm{lb}$. After the stress was removed, the specimen was inspected both visually and with penetrant for the f'ormation of cracks. No ind1cations of cracks were observed either visually or with the penetrant, so the specimen will be stressed to a higher load, $3500 \mathrm{lb}$, and inspected again.

Further experimentation was done during the penetrant inspection of this stressed specimen with a reduction in penetrant dwell time from $10 \mathrm{~min}$. to $5 \mathrm{~min}$. A comparison of the rate of removal of the excess penetrant by the solvent-removal method for the two dwell times indicates that $5 \mathrm{~min}$. is too long for this extremely porous material. Future penetrant tests will be done with dwell times in the order of 1 min.

\subsubsection{High Voltage Probe (G. W. Scott)}

We have built a simple-scanning device for use with the high voltage probe. This scanner will provide precise spacing control between the prohe and the substrate.

\subsection{Iron and Nickel Carbonyl Formation and Prevention}

J. Brynestad and J. H. DeVan

The valves for the experimental set-up were received, and the test apparatus for reaction rate studies is now fully assembled. Performance testing is underway. We were able to control temperature, pressure, and flow rate in the apparatus to the standards needed for our reaction rate determinations. Because of the safety hazards of metal carbonyls, we are being especially careful. An initial test is underway to measure the background rate of iron and nickel carbonyl formation relating to the final system itself, which is made of 316 stainless steel. Based on published data, we expect this background rate to be small but measurable. However, we don't expect the system to produce carbonyls at levels which would interfere with the testing of low alloy steels. If such should be the case, we will suppress the carbonyl formation by (1) oxidizing the heated surfaces of the apparatus, or (2) depositing copper electrolytically on the heated surfaces. The first test run will be conducted on $1 / 2 \%$ Mo 
steel piping supplied by Pittsburgh Energy Research Center. The test will be operated at $260^{\circ} \mathrm{C}$ and $1000 \mathrm{psig}$, with the gas mixture being $30 \% \mathrm{CH}_{4}, 51 \% \mathrm{H}_{2}, 17 \% \mathrm{CO}$; and the balance $\mathrm{CO}_{2}$.

\subsection{Failure Analysis of Materials and Components}

D. A. Canonico, D. P. Edmonds, and T. K. Roche

No work was performed this month. A topical report was written and is being edited covering prior work. The new procedures for conducting failure analysis were received from FER, reviewed, and our comments returned to ERDA within the ten days specified.

\subsection{Prestressed Concrete Pressure Vessel Studies \\ W. L. Greenstreet}

The objective is to investigate the potential use of prestressed concrete pressure vessels (PCPV) for coal conversion processes, to identify major problem areas, and to define and outline a test program (or programs) for feature and concept demonstration. Conceptual designs of pressure vessel and liner combinations for commercial size systems are to be developed and studied as vehicles for assessment and guidance.

Emphasis has continued on detailed analysis work necessary for conceptual design finalization. Intimately tied to these analyses are materials selections and geometrical details in the refractory-liner-vessel interface region.

Under Task 1, drawings of vessel conceptual designs incorporating details of the top closure, circumferential and vertical prestress systems, bonded reinforcement, penetrations, and vessel support structure are being prepared. The Synthane vessel drawings are being done first; completion of a number of layout details for the Synthane as well as the HYGAS vessel will depend on results from calculations now under way.

Thermal stresses in the liner are being examined along with the consequences of cyclic loading. Effects of local gradients in the anchor attachment regions are to be included in these investigations.

Under Task 4, materials for a two-layer refractory lining system selected for initial heat transfer investigations were given further study. Thermal conductivities for each of the materials (the dense, abrasion resistant inner material and the backup insulating material) were calculated assuming air in the pores is replaced by hydrogen. Extremes in porosity were used in calculating these conductivities. A doubleanchoring system using stainless steel anchors appears to be the best choice for mechanically holding the refractory in place and transferring load to the vessel. 
Difficulties in conducting thermal analyses for the refractoryliner-vessel interface region have impeded overall progress. These difficulties are being overcome, and improved progress is expected to result.

\subsection{Other Related Work}

W. W. Harris, R. H. Cooper, Jr., and J. H, DeVan

\subsubsection{Fluidized Bed Materials Support Activities}

Nothing to report. 


\section{PROCESS AND PROGRAM ANALYSIS \\ J. R. McWherter}

Process and program analysis studies are being conducted for the ERDA Fossil Energy Office of Program Planning and Analysis. This effort includes research studies on most of the coal conversion and utilization processes. The program objective is to provide, on a consistent basis, technical and economic evaluations of competing processes and systems for coal conversion and utilization.

The subprograms under review are:

(1) Low Btu Gas

(2) High Btu Gas

(3) Direct Combustion

(4) Liquefaction

(5) Advanced Power/Combined Cycle

(6) In-Situ Coal Gasification

Also included are general subjects such as beneficiation and gas cleanup.

A survey will be conducted to identify the applicable processes, concepts and systems. The survey will cover not only activities in the United States but in other countries as well. The status of development shall be determined in sufficient detail to identify the promising processes, concepts, and systems.

A list of high potential, or candidate, processes, concepts and systems, including all of those currently being funded by ERDA, will be prepared from the above survey. These candidates will be considered for detailed study. The most favorable process for each subprogram will be determined on a regional basis. The potentially competitive processes will be identified with an evaluation of what needs to be done to make them the most favorable and what the chances of success are of such proposed actions.

\subsection{Low Btu Coal Gas}

J. P. Belk, B. L. Crynes, ${ }^{*}$ H. F. Hartman, D. E. Reagan

ORNL personnel recently began a program to provide technical and economic evaluations of processes that convert coal to low and intermediate fuel gas. The following activities were completed: (1) project definition, (2) proposed method for economic comparison, and (3) outline of a Data Source Book. Work is in progress now to survey the gasification processes and select the more promising ones for detailed comparisons and evaluations. Program objectives and required information were reviewed with ERDA-FE-OPPA personnel at an August 30 meeting.

\footnotetext{
* Consultant, Oklahoma State University.
} 


\subsection{High Btu Gas}

This project will be subcontracted.

\subsection{Direct Combustion}

H. I. Bowers, O. I. Culberson, ${ }^{*}$ I. Spiewak

A preliminary work statement and discussion of this subject was submitted to ERDA for review.

\subsection{Liquetaction}

A subcontract for this project is being negotiated.

\subsection{Advanced Power/Combined. Cycle}

A. P. Fraas, M. E. Lackey, G. Samuels, W. M. Wells

A large amount of information is being collected on the development of gas turbines. A more thorough look is being taken on the use of coal in gas turbines.

\subsection{In-Situ Coal Gasification}

R. C. Forrester III and W. C. Ulrich

A preliminary work statement on this project was submitted to ERDA for review. Work is in progress to determine the status of the processes.

\subsection{Subsystems \\ O. L. Culberson ${ }^{*}$}

9.7.1 Beneficiation (G. W. Peterson)

A work statement for this project is being developed.

9.7.2 Gas Cleanup (M. S. Edwards)

A work statement was prepared for this project. A review of the information available is in progress.

* Consultant, University of Tennessee. 


\section{ALTERINATE CONTACTORS FOR NONCATALYTIC HYDROLIQUEFACTION OF COAL}

J. R. Hightower, Jr., and R. C. Lovelace

Improvements in hydrodesulfurization and hydroliquefaction of coal in hydrogen donor solvent systems can possibly be achieved by improving the design of the reactor in which the hydrogenation is carried out. Results obtained in the development of the Synthoil process ${ }^{1}, 2$ at Pittsburgh Energy Research Center (PERC) suggest that under conditions of high turbulence and plug flow in a reactor, adequate desulfurization and liquefaction may be achieved utilizing only the catalytic activity of the ash minerals. The objective of the work reported here is to demonstrate that a highly turbulent plug flow reactor of novel design would allow adequate hydrodesulfurization and hydroliquefaction without the use of hydrotreating catalysts. The work is divided into two phases: (1) simulated contactor studies which have the objective of identifying suitable reactor configurations (we will investigate a reactor consisting of several venturis in series and one with vortex flow similar to a cyclone device) through tests with water/coal slurries and air, and (2) hydrogenation verification studies in which coal is hydrogenated in a suitable reactor whose design would be based upon results from the first phase studies.

Progress on the first phase (simulated contactor studies) since the start of the project (in July 1976) has consisted of a review of the literature for flow characteristics of venturis operating with gasliquid or liquid-solid two-phase flow and the design and start of installation of a facility to circulate water/coal slurries through a three-phase contactor and to measure pressure drop across and residence time distributions in the contactor.

\section{I References for Section 10}

1. I. Wender, Internal Quarterly Technical Progress Report, Oct.-Dec. 1975, PERC/QTR-75/4, January 1976, p. 22.

2. I. Wender, Internal Quarterly Technical Progress Report, Jan.-Mar. 1976, PERC/QTR-76/1, April 1976, p. 48. 
THIS PAGE

WAS INTENTIONALLYY

LEFT BLANK 
1. R. G. Affel

2. T. D. Anderson

3. S. I. Auerbach

4. R. E. Barker

5. M. Bender

6. N. E. Bolton

7. C. R. Boston

8. R. E. Brooksbank

9. D. A. Canonico

10. J. A. Carter

11. B. R. Clark

12. H. D. Cochran, Jr.

13. E. Copenhaver

14. I. T. Corbin

15. O. L. Culberson

16. F. L. Culler

17. J. E. Cunningham

18. V. A. DeCarlo

19. D. G. Doherty

20. M. S. Edwards

21. F. J. Endelman

22. J. L. Epler

23. G. G. Fee

24. D. E. F'erguson

25. L. M. Ferris

26. R. C. Forrester III

27. A. P. Fraas

28. W. Fulkerson

29. W. R. Gambill

30. R. B. Gammage

31. D. A. Gardiner

32. C. W. Gehrs

33. J. B. Gibson

34. W. L. Greenstreet.

35. M. R. Guerin

36. C. W. Hancher

37. L. A. Harris

38. S. E. Herbes

39. S. G. Hildebrand

40. R. M. Hill

4I. R. S. Holcomb

42. J. M. Holmes

43. J. K. Huffistietier

44. C. L. Hunt

45. G. R. Jasny, $Y-12$
46. R. L. Jolley

47. J. E. Jones

48. D. S. Joy

49. S. Katz

50. O. L. Keller

51. W. R. Laing

52. R. S. Livingston

53. A. P. Malinauskas

54. G. B. Marrow

55. W. R. Martin

56. C. J. McHargue

57. J. R. McWherter

58. H. J. Metz

59-61. W. R. Mixon

62. J. E. Mrochek

63. P. Nettesheim

64-70. J. P. Nichols

71. L. C. Oakes

72. G. R. Peterson

73-74. T. W. Pickel

75. W. W. Pitt

76. H. Postma

77. W. T. Rainey, Jr.

78. D. E. Reichle

79. C. R. Richmond

80. B. R. Rodgers

81. M. W. Rosenthal

82. T. H. Row

83. W. L. Russell

84. Royes Salmon

85. R. W. Schede

86. C. D. Scott

87.' A. J. Shor

88, D, S. Shriner

89. W. D. Shults

90. C. B. Smith

91. G. P. Smith

92. I. Spiewak

93. R. $T_{s}$. Spore

94. E. G. St. Clair

95. J. B. Storer

96. R. A. Strehlow

97. O. K. Tallent

98. A. J. Thompson

99. D. B. Trauger

100. W. C. Ulrich 
101. P. R. Vanstrum

102. J. S. Watson

103. J. R. Weir

104. P. R. Westmoreland

105. M. K. Wilkinson

106. L. V. Wilson

107. R. G. Wymer
108. C. S. Yust

109. J. R. Hightower

110. Patent Office

111. Lab. Records-RC

112-118. Lab. Records

119-121. Central Research Library

122. Document Reference Section

\section{EXTERNAL DISTRIBUTION}

ERDA, Oak Ridge Operations

123. Research and Technical Support Division

ERDA, Washington

124. W. Bakker, FER

125. D. Ballantine, DBIR

126. J. D. Batchelor, CCU

127. T. Beresovski, RD\&D

128. C. E. Carter, DBER

129. E. L. Clark, CCU

130. N. P. Cochran, FDP

131. P. Duhamel, FER

132. C. W. Edington, DBER

133. H. Frankel, FER

134. R. Franklin, DBER

135. D. Garrett, FDP

136. S. W. Gouse, FE

137. W, S. Harmon, FDP

138. L. Kindley, FER

139. C. Knudsen, FER

140. T. K. Lau, CCU

141. R. W. A. LeGassie, AA/PA

142. J. L. ILvermar1, $A A /$ II
143. W. G. MoDaniel, FE

144-150. C. Miller, CCU

151. G. A. Mills, FER

152. W. E. Mott, DBER

153. M. B. Neuworth, CCU

154. E. S. Pierce, DPR

155. H. E. Podall, FER

156. J. L. Powell, FDP

157. M. Reilly, FE

158. John Shen, FERR

159. D. H. Slade, DBER

160. G. Stapleton, DBER

161. D. K. Stevens, DPR

162. H. Wasson, DBER

163. P. C. White, AA/FE

164. P. R. Wieber, OGST

165. R. W. Woud, DBER

166. R. I. Zahradnik, CCU

Department of Housing and Urban Development, 451 th Street, S.W., Washington, DC 20410

167. G. S. Leightion

168. J. H. Rothenberg

National Science Foundation, 1800 G Street, N.W., Washington, DC 20550 169. R. S. Goor

170. Robert Rabin

Resource Planning Associates, Inc., 44 Brattle St., Cambridge, MA 02138 171. Robert Rea

U.S. Environmental Protection Agency, ETRL, 1055 Laidlow, Cincinnati, $\mathrm{OH} 4523 \%$

172. William E. Pepelko

U.S. Environmental Protection Agency, Research Triangle Park, NC 27711 173. Charles B. Sedman 
U.S. Steel Corporation Applied Research Laboratory, 125 Jamison Lane, Monroeville, PA 15146

174. N. S. Boodman, Section Supervisor

University of Kentucky, Institute for Mining and Materials Research, 213 Bradley Hall, Lexington, KY 40506

175. Theresa Wiley, Institute Librarian

176. 0. J. Haun

177. J. K. Shou

178-189. ERDA Pittsburgh Energy Research Center, U.S. Energy Research and Development Administration, Attention Director for J. P. Barreca, 4800 Forbes Ave., Pittsburgh, PA 15213

190-195. The Director, Morgantown Energy Research Center, P.0. Box 800, Morgantown, WV 26506

196. A. K Ingberman, I Penn Plaza, Coalcon, New York, NY 10001

197. R. E. Davis, Kerr-McGee Technical Center, P.O. Box 25861, Oklahoma City, OK 73125

198. H. Beuther, Gulf Research and Development Company, P.O. Drawer 2038, Pittsburgh, PA 15230

199. Robert Hangebrauck, National Environmental Research Center, Research Triangle Park, NC 27711

200. P. H. Given, Pennsylvania State University, College of Earth and Mineral Sciences, University Park, PA 16802

201. John W. Larson, Department of Chemistry, University of Tennessee, Knoxville, TN 37916

202. Wendall H. Wiser, University of Utah, Department of Mineral Engineering, Salt Lake City, UT 84112

203. William A. Peters, Massachusetts Institute of Technology, Department of Chemical Engineering, Cambridge, MA 02139

204. Donald Hanson, University of California, Department of Chemical Engineering, Berkeley, CA 94720

205. S. G. Wellborn, Manager, Feedstocks Development, E. I. du Pont de Nemours \& Company, Inc., Wilmington, $\mathrm{DE} 19898$

206. Tetra Tech, Inc., 1911 N. Ft. Myer Drive, Suite 601, Arlington, VA 22209, Attention: Walter McGough, Jr.

207-208. Jack Gillespie, UCCND, P.O. Box 1410, Paducah, KY 42001

209. Jerry D. Kennedy, Sandia Laboratories, P.O. Box 5800, Albuquerque, NM 87115

210. I B. Batta, Coalcon, P.0. Box 44, Tonawanda, NY 14150

211. Emmett J. Ferretti, Synthetic Fuels Department, Dravo Corp., P. O. Box 235, Library, PA 15129

212. 0. L. Anderson, Institute of Geophysics \& Planetary Phys., University of Califormia, Los Angeles, CA 90024

213. S. K. Chakrabartty, Alberta Research Council, Fuel Sciences Div., $1131 \%-87$ th Ave., Edmonton, Alberta, Canada T6G 2C2

214. E. H. Reichl, Vice-President, Consolidation Coal Co., Library, PA 15129

215. Cameron Engineers, Attn: Gary L. Baughman, 1315 South Clarkson St. , Denver, Co 80210

216-242. Technical Information Center, ERDA 